\title{
Computation Elements for Sizing Gas Depollution Installations
}

\author{
M. F. Ştefănescu ${ }^{1}$, I.A. Sima $^{2} \&$ M. Constantin ${ }^{3}$ \\ ${ }^{1}$ Professor Dr. Eng., ${ }^{2}$ PhD Student, ${ }^{3}$ Sl. Dr. Eng., Faculty of Mechanical Engineering and Mechatronics, \\ Department of Thermodynamics, Engines, Thermal and Refrigerating Equipment's, University Politehnica of Bucharest, \\ Romania.Email: i.mihaelaconstantin@gmail.com ${ }^{3}$ \\ DOI: http://doi.org/10.38177/ajast.2021.5103
}

Copyright: (C2021 M.F.Ştefãnescu et al. This is an open access article distributed under the terms of the Creative Commons Attribution License, which permits unrestricted use, distribution, and reproduction in any medium, provided the original author and source are credited.

\section{ABSTRACT}

The paper determines the driving and absorption speed of a particle to a cyclone. The particle has the shape of a sphere with a diameter of 5 mm and is made of polyethylene. The drag resistance on horizontal and vertical directions is calculated and the air flow rate that drives these particles tha separate into the cyclone is determined. Finally, the minimum power required by the fan to ensure that these particles move to the cyclone is calculated.

Keywords: Gas depollution, Cyclones.

\section{INTRODUCTION}

In general, depollution installations concern both liquid and gaseous environments; this paper refer only to some aspects regarding the gas's depollution, i.e., the gases separation (air or flue-gases) from solid particles suspended in that gas.

The methods used to separate heterogeneous systems can be divided into the following main groups [1] [2]:

I. Mechanical or dry gas separation, in which the sedimentation of the particles is performed under the action of mechanical forces. The separation (purification, dusting, mechanical purification) can be performed by:

a) Sedimentation chambers also called deposition chambers, where the sedimentation of particles is done under the action of gravitational force;

b) Cyclones, where the particles sedimentation is done under the action of centrifugal force.

II. Wet gases separation by passing them through a layer of liquid or by spraying with liquid. Wet separation can be performed with:

a) Scrubbers;

b) Wet surface devices;

c) Foam devices.

III. The gases filtration through porous materials, which does not allow particles suspended in the gas to pass through. Gas filtration can be performed with bag filters.

IV. Electrical gases separation by sedimentation of gas-dispersed particles in a high voltage electric field. Electrical separation can be done with:

a) Tubular electric filters; 
b) Electric plate filters;

c) Tubular electric filters with plates.

Dust discharges in various closed or semi - open premises (crushing stations of coal, concrete preparation stations, coal bunkers; conveyor belts with sand, coal, cement, etc.) must not exceed the limits allowed by the republican norms of labor protection; thus, for coal dust the maximum concentration allowed in the air is $15 \mathrm{mg} / \mathrm{m}^{3}$.

Industrial ventilation and air conditioning systems aim to ensure air purity and microclimate conditions corresponding to human activity and the nature of the technological process. The local suction installations through the generated air speed, achieve a limitation of the harmfulness spread, ensuring at the same time the minimum openings necessary for the development of technological processes. The devices used must ensure the most complete capture of harmful emissions, do not impede the production process and allow a normal position of the worker, so that it is not between the harmfulness source and the suction opening. These installations consist of the capture device, the cyclone, the fan and the connecting pipes. Hoods are local devices for aspiration of harmful substances, located above, sideways or below the sources. Because the tests will be performed in a laboratory within the Department of Thermotechnics, Engines, Thermal and Refrigeration Equipment's one cannot destroy the laboratory architecture; as a result, no particles of cement, coal dust, sand, etc. will be studied, but plastic particles will be used. Small polyethylene particles of medium density are considered: $\rho=1250 \mathrm{~kg} / \mathrm{m}^{3}$, spherical in shape with a diameter of $5 \mathrm{~mm}$.

\section{THE SKETCH OF THE INSTALLATION FOR RESEARCHES ON THE GAS DYNAMICS OF} ABSORPTION HOODS

Figure 1 shows the experimental installation designed and built within the Department of Thermotechnics, Engines, Thermal and Refrigeration Equipment's.

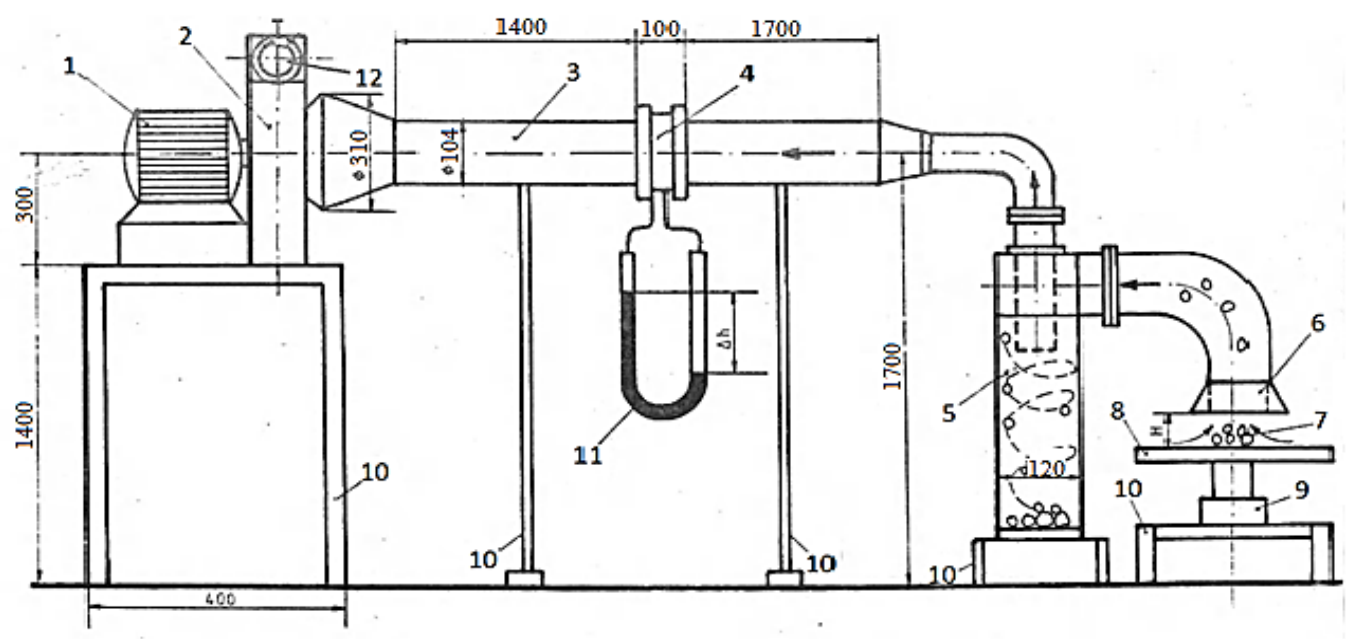

Fig.1. The Sketch of the Experimental Installation

1 - electric motor; 2 - centrifugal fan; 3 - suction pipe; 4 - diaphragm; 5 - cyclone; 6 - absorption hood; 7 - particles; 8 - observation plate; 9 - lifting device; 10 - supports; 11 - differential manometer; 12 - damper for regulating the air flow rate 


\section{A TAST}

Asian Journal of Applied Science and Technology (AJAST)

Volume 5, Issue 1, Pages 21-29, January-March 2021

The centrifugal fan (2) draws air from the atmosphere and moves the particles (7) on the observation plate (8). These particles are absorbed into the cyclone (5), where are deposited at the base of the cyclone under the effect of centrifugal force. Clean air (without particles) is absorbed by the fan through the duct (3) and blown into the atmosphere. The air flow rate corresponding to the drive speed $\left(\dot{V}_{\text {drive }}\right)$ and the absorption speed $\left(\dot{V}_{\text {drive }}>\dot{V}_{a b s}\right)$ are measured using the diaphragm (4); from the characteristic curve of the diaphragm results the flow rate conveyed by the fan. The plastic particles to be captured by the cyclone (5) are placed on the observation plate (8) of figure 1. The air flow rate to drive these particles is measured with the diaphragm (4).

The manometer indication (11) helps to find out the air flow rate conveyed by the fan, from figure 2 .

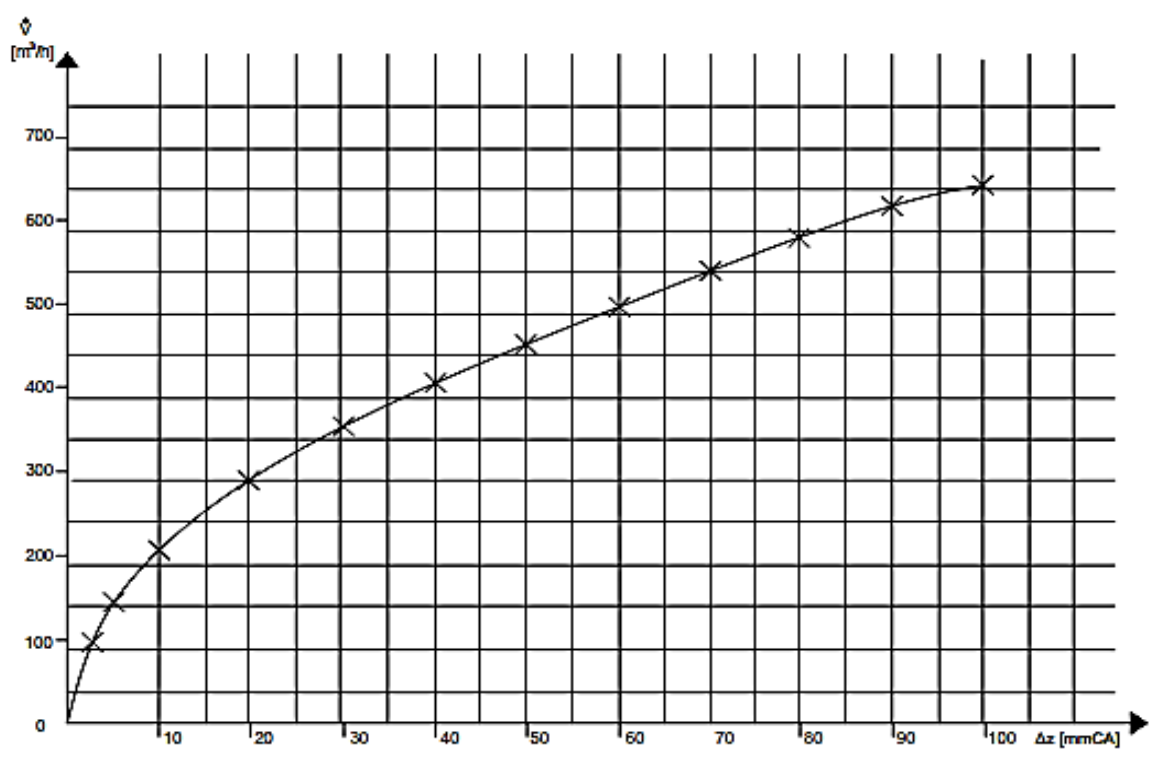

Fig.2. The Characteristic Curve of the Diaphragm: $\dot{V}=f(\Delta h)$

For a certain air flow rate aspirated by the fan, the particles placed on a circle with radius $r_{1}=0.1 \mathrm{~m}$ were entrained towards the center of the plate.

In this case, the pressure drop on the diaphragm was $\Delta \mathrm{h}=13 \mathrm{mmH}_{2} \mathrm{O}$ and from figure 2 it results: $\mathrm{V}_{\mathrm{x}}=245 \mathrm{~m}_{3} \mathrm{~h}=$ $0.068 \mathrm{~m}^{3} / \mathrm{s}$.

\section{FORCES ACTING ON THE PARTICLE, IN THE HORIZONTAL DIRECTION (Ox AXIS) AND IN THE VERTICAL DIRECTION (Oz AXIS)}

The motion of the particle on plate 8 (figure 1 ) is considered to be rectilinear and uniform $(\mathrm{w}=\mathrm{ct}$ ).

The problem is to set a minimum speed of air flow rate to move a spherical particle in motion on a horizontal surface. The particle can move in two ways [3] [4]:

a) by crawling;

b) by rolling.

The air current act on the particle with a force given by the speed of the current that creates a dynamic pressure, which multiplied by the area of the particle section generates a force $\mathrm{F}$ (figure 3 ). 


\section{NUAST}

Asian Journal of Applied Science and Technology (AJAST)

Volume 5, Issue 1, Pages 21-29, January-March 2021

According to the principle of action and reaction in mechanics, an opposite force $\mathrm{R}_{\mathrm{x}}$ will appear, which is the very horizontal drag resistance of the particle, i.e., along the Ox axis (figure 3).

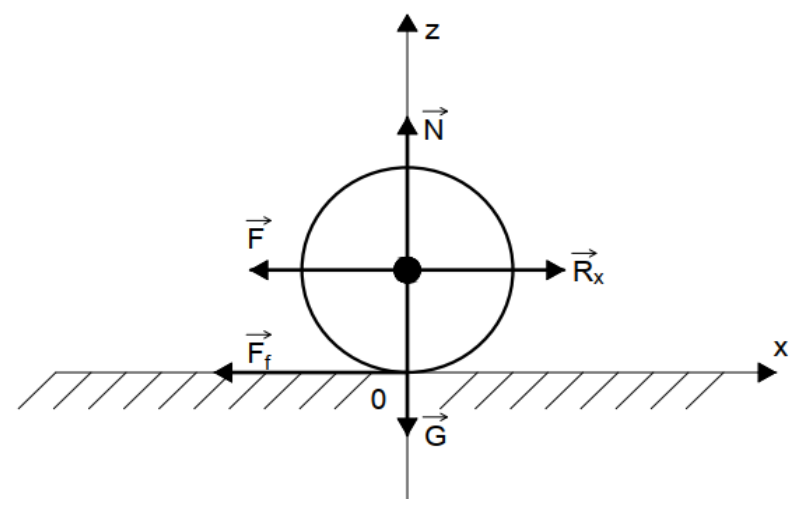

Fig.3. Horizontal Particle Equilibrium

The friction force between the plane and the particle opposes the force $\mathrm{R}_{\mathrm{x}}$. On the $\mathrm{Oz}$ axis there is the normal reaction to the horizontal plane $(\mathrm{N})$ and the weight of the particle [5].

$N=G[N] ; F_{f}=\mu \cdot N=\mu m g[N] \rightarrow(\mathbf{1})$

The particle will be entrained by crawling (the hardest case compared to a rolling motion of the particle) when the drag resistance in the horizontal direction $\left(\mathrm{R}_{\mathrm{x}}\right)$ will be greater than the frictional force between the particle and the observation plate $\left(\mathrm{F}_{\mathrm{f}}\right)$.

$R_{X}>F_{f} ; R_{X}>\mu m g[N] \rightarrow(2)$

Horizontal drag resistance, along the Ox axis.

The drag resistance of the particle considering it as a small sphere is given by the relation [6]:

$R_{x}=C_{x} \frac{\rho}{2} w_{x}^{2} A[N] \rightarrow$

where: $\mathrm{C}_{\mathrm{x}}$ - is the drag resistance coefficient along the Ox axis;

$C_{x}=\frac{24}{\operatorname{Re}}\left(1+\frac{3}{16} \operatorname{Re}\right) \rightarrow(4)$

$\operatorname{Re}=\frac{w_{x} \cdot d}{v} \rightarrow$

$\rho$ - the air density $\left[\mathrm{kg} / \mathrm{m}^{3}\right]$;

$\mathrm{w}_{\mathrm{x}}$-the horizontal air speed $[\mathrm{m} / \mathrm{s}]$;

A - the area of the particle section, perpendicular to the air flow rate direction $\left[\mathrm{m}^{2}\right]$.

$A=\frac{\pi d^{2}}{4}=\frac{\pi}{4}\left(5 \cdot 10^{-6}\right)^{2}=19.62 \cdot 10^{-6} \mathrm{~m}^{2} \rightarrow$ 


\section{NUAST}

$v$ - kinematic viscosity of the air $\left[\mathrm{m}^{2} / \mathrm{s}\right]$.

The following are known:

- The particle diameter: $5 \cdot 10^{-3} \mathrm{~m}$

- The air temperature: $\mathrm{t}=20^{\circ} \mathrm{C}$

- The air viscosity for $\mathrm{t}=20^{\circ} \mathrm{C}: \mathrm{v}=14.61 \cdot 10^{-6} \mathrm{~m}^{2} / \mathrm{s}$

- The air density is from the equation of state:

$\rho=\frac{p}{R T}=\frac{101325.0}{287(20+273.15)}=1,2 \mathrm{~kg} / \mathrm{m}^{3} \rightarrow(\mathbf{7})$

After entering the hood, in the vertical direction (Oz axis) the particle will move vertically if the drag resistance along the $\mathrm{Oz}$ axis $\left(\mathrm{R}_{\mathrm{z}}\right)$ will be greater than the weight of the particle $(\mathrm{G})$ (figure 4).

$R_{z}>G \rightarrow(8)$

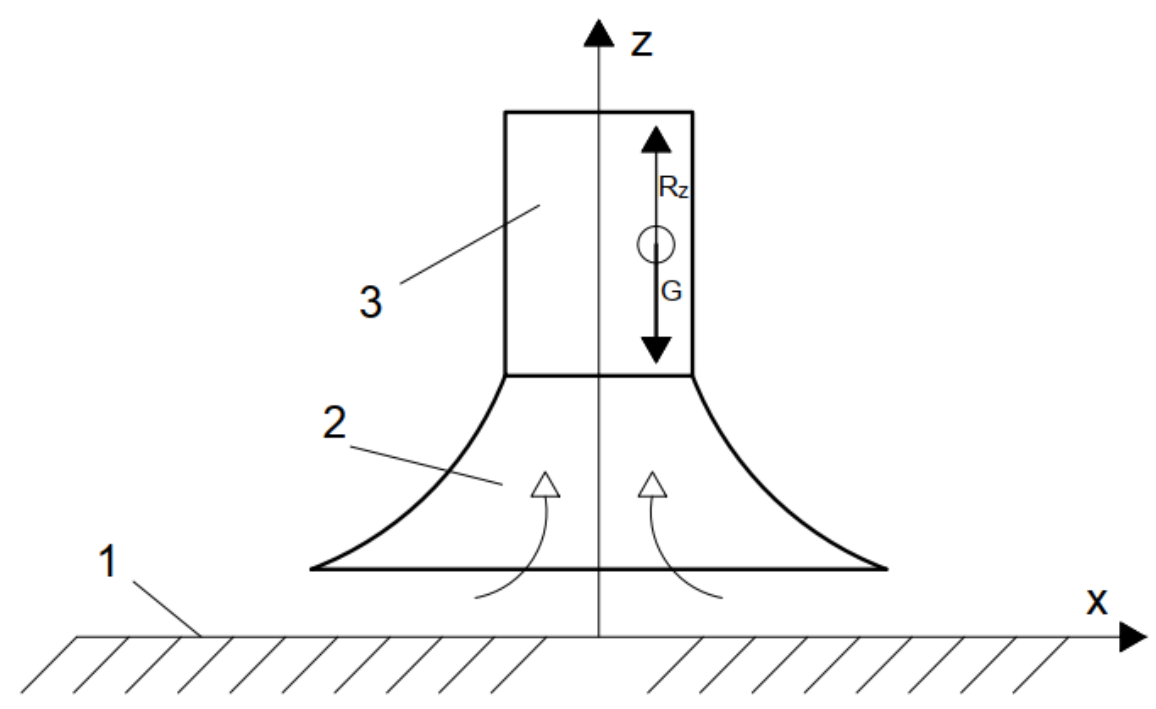

Fig.4. Vertical Force Equilibrium

\section{1 - Flat Plate; 2 - Absorption Hood; 3 - Suction Pipe to the Cyclone}

The drag resistance to vertical along the $\mathrm{Oz}$ axis is given by the relation [6] [7]:

$R_{z}=C_{z} \frac{\rho}{2} w_{z}^{2} A[N] \rightarrow(\mathbf{9})$

relation where: $\mathrm{C}_{z}$ - is the drag resistance coefficient along the Oz axis;

$C_{z}=\frac{24}{\operatorname{Re}}\left(1+\frac{3}{16} \operatorname{Re}\right) \rightarrow(\mathbf{1 0})$ 
$\operatorname{Re}=\frac{w_{z} \cdot d}{v} \rightarrow$

$\rho$ - the air density $\left[\mathrm{kg} / \mathrm{m}^{3}\right]$;

$\mathrm{w}_{\mathrm{z}}$ - the vertical air speed $[\mathrm{m} / \mathrm{s}]$;

A - the area of the particle section $\left[\mathrm{m}^{2}\right]$.

$\mathrm{d}$ - the particle diameter $[\mathrm{m}]$.

\section{COMPUTATION OF THE FRICTION FORCE BETWEEN THE PARTICLE AND THE PLATE}

The friction force between the particle and the observation plate is calculated with the relation [6]:

$F_{f}=\mu_{m_{p}} g[N] \rightarrow$

wherein:

- $\mu$ - the friction coefficient between the particle and the plate;

- $\mathrm{m}_{\mathrm{p}}$ - the particle mass $[\mathrm{kg}]$;

- g - gravitational acceleration $\left[\mathrm{m} / \mathrm{s}^{2}\right]$.

The following are known:

$-\mu-=0.2$

- $\mathrm{m}_{\mathrm{p}}$ - the particle mass $[\mathrm{kg}]$

$m_{p}=\rho_{p} V_{p}=\rho_{p} \cdot \frac{4}{3} \pi\left(\frac{d}{2}\right)^{3}[k g] \rightarrow(\mathbf{1 3})$

where: $\rho_{\mathrm{p}}$ - the polyethylene particle density: $\rho=1250 \mathrm{~kg} / \mathrm{m}^{3}$.

$m_{p}=\rho_{p} \cdot V=1250 \cdot \frac{4}{3} \pi\left(5 \cdot 10^{-6}\right)^{3}=0.0817 \cdot 10^{-3} \mathrm{~kg} \rightarrow \mathbf{( 1 4 )}$

The particle weight:

$G=m_{p} g=0.0817 \cdot 10^{-3} \cdot 10=0.817 \cdot 10^{-3} N \rightarrow$

The friction force will be:

$F_{f}=\mu G=0.2 \cdot 0.817 \cdot 10^{-3}=0.163 \cdot 10^{-3} N \rightarrow$ (16)

5. THE DETERMINATION OF THE MINIMUM HORIZONTAL AND VERTICAL PARTICLE TRANSPORT SPEED

5.1 THE DETERMINATION OF THE MINIMUM HORIZONTAL PARTICLE TRANSPORT SPEED 
Taking into account the shape and size of the particle presented in paragraph 2, the minimum speed of the air stream that ensures the horizontal movement of the particle will be determined.

The minimum horizontal particle transport speed is obtained by equalizing the drag resistance $\left(\mathrm{R}_{\mathrm{x}}\right)$ to the frictional force between the particle and the flat plate [6]:

$$
\begin{aligned}
& R_{x}=F_{f}[N] \rightarrow(\mathbf{1 7}) \\
& C_{x} \frac{\rho}{2} w_{x}^{2}=\mu m_{p} g \rightarrow(\mathbf{1 8}) \\
& w_{x}=\sqrt{\frac{2 \mu m_{p} g}{C_{x} \rho A}}[\mathrm{~m} / \mathrm{s}] \rightarrow(\mathbf{1 9}) \\
& w_{x}=\sqrt{\frac{2 \cdot 0.2 \cdot 0.081 \cdot 10^{-3} \cdot 10}{4.5 \cdot 1.2 \cdot 19.62 \cdot 10^{-6}}}=1.74[\mathrm{~m} / \mathrm{s}] \rightarrow \mathbf{( 2 0 )}
\end{aligned}
$$

\subsection{THE DETERMINATION OF THE MINIMUM VERTICAL PARTICLE TRANSPORT SPEED}

The air speed center on the vertical ( $\mathrm{Oz}$ axis) must create a dynamic pressure on the spherical particle so as to overcome the weight of the particle. As a result, the minimum vertical transport speed for a spherical particle is determined by equalizing the vertical drag resistance $\left(R_{z}\right)$ with the particle weight $(G)$.

$$
\begin{aligned}
& R_{z}=G[N] \rightarrow(\mathbf{2 1}) \\
& C_{z} \frac{\rho}{2} w_{z}^{2} A=m_{p} g[N] \rightarrow(\mathbf{2 2}) \\
& w_{z}=\sqrt{\frac{2 m_{p} g}{C_{z} \rho A}}[\mathrm{~m} / \mathrm{s}] \rightarrow(\mathbf{2 3}) \\
& w_{z}=\sqrt{\frac{2 \cdot 0.081 \cdot 10^{-3} \cdot 10}{4.5 \cdot 1.2 \cdot 19.62 \cdot 10^{-6}}}=12.385[\mathrm{~m} / \mathrm{s}] \rightarrow(\mathbf{2 4}) \\
& \text { 6. COMPUTATION OF THE THEORETICAL POWER FOR THE PARTICLES MOVEMENT } \\
& \text { TOWARDS THE CYCLONE }
\end{aligned}
$$

\section{COMPUTATION OF THE THEORETICAL POWER FOR THE PARTICLES MOVEMENT TOWARDS THE CYCLONE}

\subsection{THE POWER REQUIRED TO DRIVE THE PARTICLE TO MOVE HORIZONTALLY}

For a single particle, the following are known:

$$
F_{f}=0.163 \cdot 10^{-3}[N] ; w_{x}=1.74[\mathrm{~m} / \mathrm{s}] \rightarrow
$$

The power calculation relation is known [6] [8]: 
$P=\frac{L}{\tau}=F \cdot w_{m}[W] \rightarrow(\mathbf{2 6})$

$P=0.163 \cdot 10^{-3} \cdot 1.74=0.283 \cdot 10^{-3}[W] \rightarrow(27)$

If a number of particles is placed on the circle of radius $r=0.1 \mathrm{~m}$ :

$n=\frac{L}{d_{p}}=\frac{2 \pi r}{d_{p}}=\frac{2 \pi \cdot 0.1}{0.005}=125.6$

The power consumed for horizontal drive will be:

$P_{h}=0.283 \cdot 10^{-3} \cdot 125.6=35.62 \cdot 10^{-3}[W] \rightarrow(29)$

\subsection{THE POWER REQUIRED TO DRIVE THE PARTICLE TO MOVE VERTICALLY}

In the case of a single particle the required driving power:

$P=F \cdot w_{z}[W] \rightarrow(\mathbf{3 0})$

$\left.F=G=0.81 \cdot 10^{-3}[N] ; w_{z}=12.385[\mathrm{~m} / \mathrm{s}] \rightarrow \mathbf{( 3 1}\right)$

$P=0.81 \cdot 10^{-3} \cdot 12.385=10.03 \cdot 10^{-3} W$

In the case of vertical displacement of particles, $n=125.6$ particles are considered.

$P_{v}=10.03 \cdot 125.6 \cdot 10^{-3}=1.260 \mathrm{~W} \rightarrow \mathbf{( 3 3 )}$

Both the horizontal displacement $\left(\mathrm{P}_{\mathrm{h}}\right)$ and the vertical displacement $\left(\mathrm{P}_{\mathrm{v}}\right)$ resulted in the following theoretical particle driving powers:

$P_{h}=0.03562[W] \rightarrow$

$P_{v}=1.26 \mathrm{~W} \rightarrow(\mathbf{3 5})$

\section{CONCLUSIONS}

a) The theoretical part of the paper specifies the conditions under which certain particles can be entrained by an absorption hood and subsequently retained in a cyclone or a battery of cyclones connected in series or in parallel.

b) The design of the installation is an original solution for the suction path of medium pressure polyethylene particles.

c) The presented computations are a calculation method of the power required to move the particle.

\section{Declarations}

Source of Funding 
This research did not receive any specific grant from funding agencies in the public, commercial, or not-for-profit sectors.

\section{Competing Interests Statement}

The authors declare no competing financial, professional and personal interests.

\section{Consent to participate}

\section{Not Applicable}

\section{Consent for publication}

We declare that we consented for the publication of this research work.

\section{Availability of data and material}

Authors are willing to share data and material according to the relevant needs.

\section{REFERENCES}

1) Voicu, V., Tehnica desprăfuirii aerului, Editura Tehnică, Bucureşti, 1988.

2) *** Contract de cercetare științifică nr. 17-8-6/18.08.1998, I.P.B. cu tema "Soluții pentru reducerea concentrațiilor de praf de cărbune din centralele electrice la nivelul concentrațiilor și dispersiilor maxime admise”, Beneficiar I.E. Borzești.

3) Slot, R. E., Terminal velocity formula for objects in a viscous fluid, Journal of Hidraulic Research, vol. 22, nr. 4, 1984 , p. $235-245$.

4) Bratu, E., Operații și utilaje în industria chimică, vol. 1, vol. 2, Editura Tehnică, bucurești, 1969.

5) Florea, Julieta, Robescu, D., Hidrodinamica instalațiilor de transport hidropneumatic și de depoluare a apei și a aerului, Editura Didactică și Pedagogică, București, 1982.

6) Băran, N., Răducanu, P., ş.a., Termodinamică tehnică, Editura POLITEHNICA PRESS, Bucureşti, 2010

7) Robescu, D., Dinamica fluidelor polifazice şi nenewtoniene, I.P.B., 1991.

8) Băran, N., Băran, Gh., Noi soluții pentru instalațiile de desprăfuire aferente stațiilor de concasare a cărbunelui din termocentrale, Energetica, vol. 38, nr. 3 - 4, pp. 131 - 135 . 